\title{
OD SPRZECIWU DO OPORTUNIZMU - POSTAWY PRZEDSTAWICIELI POLSKIEGO ŚRODOWISKA LITERACKIEGO WOBEC SPRAWY LISTU 34
}

\begin{abstract}
Streszczenie. List 34 był protestem polskich pisarzy i naukowców przeciwko polityce kulturalnej PZPR skierowanym do władz w marcu 1964 r. Wywołał on reakcję rządzących oraz społeczeństwa, zarówno w kraju, jak i za granicą. W artykule krótko zarysowano genezę dokumentu, przebieg zbierania podpisów oraz rozpowszechniania memoriału. Wskazano też konsekwencje wynikające z podpisania go przez sygnatariuszy. Skupiono się na scharakteryzowaniu postaw przedstawicieli środowiska literackiego wobec sprawy Listu 34.

Pisarze zostali podzieleni na trzy grupy - sygnatariuszy, zwolenników polityki Partii oraz tych, którzy zgadzali się z ideą protestu, choć go nie podpisali. Ich postawy omówiono na przykładach konkretnych wydarzeń związanych ze sprawą Listu 34, m.in. spotkań literatów z przedstawicielami władzy, stworzenia kontrlistu oraz walnego zebrania Oddziału Warszawskiego ZLP. Opisane zostało również dwuznaczne podejście do sprawy protestu prezesa związku pisarzy - Jarosława Iwaszkiewicza. Można stwierdzić, że solidarność przedstawicieli omawianego środowiska była częstsza niż głosy potępienia, choć funkcjonowała również grupa literatów partyjnych, którzy nie popierali idei dokumentu. List 34 przyczynił się do podziału w ZLP oraz stanowił zapowiedź większego protestu z roku 1968.
\end{abstract}

Słowa kluczowe: List 34, pisarze, literatura, kultura, PRL, cenzura, polityka kulturalna, opozycja, oportunizm, Gomułka, Iwaszkiewicz, Słonimski.

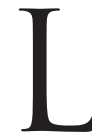

ist 34 był pierwszym powojennym sprzeciwem społecznym na tak dużą skalę - podpisały go osoby z czołówki literatury i nauki, z sygnatariuszami solidaryzowano się w całym kraju, a także za granicą. Postaram się na wybranych przykładach opisać postawy przedstawicieli polskiego 
środowiska literackiego wobec sprawy tego protestu. Najpierw krótko zarysuję genezę Listu 34, przebieg zbierania podpisów oraz rozpowszechniania memoriału. Wskażę również konsekwencje wynikające z podpisania dokumentu przez sygnatariuszy. Przedstawiciele środowiska literackiego podzieleni zostali na trzy grupy. Pierwszą tworzy kilkanaście znaczących postaci, które podpisały protest. Druga składa się z pisarzy jawnie opowiadających się za polityką Partii. Jako ostatnią grupę można wyróżnić literatów, którzy nie podpisali protestu, ale zgadzali się z jego ideą.

Pierwsza połowa okresu rządów Władysława Gomułki wydaje się stosunkowo spokojna - społeczeństwo jeszcze wierzyło w zapowiadane od Października zmiany, a o masowych strajkach z Marca i Grudnia nikt jeszcze nie myślał. Na tę pozorną idyllę cieniem kładzie się 1964 r., kiedy przeciwko polityce kulturalnej zaprotestowali intelektualiści. Pewne formy sprzeciwu wobec odgórnej i upolitycznionej cenzury pojawiały się jednak już wcześniej. Kiedy Antoni Słonimski w 1956 r. został przewodniczącym Związku Literatów Polskich (ZLP), chciał, by organizacja spełniała głównie zadania materialne. Spotkał się także z premierem Józefem Cyrankiewiczem w sprawie złagodzenia cenzury ${ }^{1}$. Przeciw ograniczeniom wolności słowa wypowiadał się wtedy także Stefan Kisielewski, który przedstawił listę około 30 tysięcy tytułów z różnych dziedzin, które nie zostały dopuszczone do druku. Żądał ujawnienia kryteriów, jakimi kieruje się GUKPPiW, i pisemnego wyjaśnienia odmowy publikacji. Głos krytyczny wobec polityki kulturalnej zabrali też m.in. Paweł Hertz, Jan Kott i Mieczysław Jastrun². Te protesty nie przyniosły jednak rezultatu, czego dobitnym dowodem była konfiskata nakładu dwóch tomów przedwojennych recenzji Antoniego Słonimskiego w 1959 r. W tym samym roku przewodniczącym ZLP został Jarosław Iwaszkiewicz, mający opinię ugodowca. Na początku lat sześćdziesiątych zaczęto zmniejszać przydziały papieru na cele wydawnicze i nakłady pism, które nie podążały bezkrytycznie za linią polityki Partii - „Przeglądu Kulturalnego” i „Nowej Kultury". Już w 1963 r. oba tygodniki zostały zlikwidowane, a na ich miejsce pojawiła się „Kultura” warszawska w pełni podporządkowana władzom oraz bojkotowana przez opozycyjnych intelektualistów. Część pisarzy wcześniej związanych z PZPR, m.in. Adam Ważyk czy Jerzy Andrzejewski, stopniowo zaczęła się od niej odwracać i szukać możliwości sprzeciwu.

List 34 powstał, bo cenzura była taka niemożliwa, że nic nie można było napisać ${ }^{3}$ - tak Stefan Kisielewski krótko nakreślił genezę protestu z 1964 r. Rozmowy o nim odbywały się już wcześniej, a podczas zebrania plenarnego

\footnotetext{
${ }^{1}$ J. Kuciel-Frydryszak, Słonimski. Heretyk na ambonie, Warszawa 2012, s. 117.

2 Ibidem, s. 117-118.

3 T. Jastrun, Mysz, która ryknęła, „Res Publica Nowa” 1994, nr 3, s. 6.
} 
Zarządu Głównego ZLP w styczniu 1964 r. Antoni Słonimski, Stanisław Cat-Mackiewicz i Melchior Wańkowicz zarzucali władzy doprowadzenie do zacofania kulturalnego, ograniczanie nakładów książek i ostrą cenzurę ${ }^{4}$. Pojawiły się dwie koncepcje oficjalnej formy protestu - jako obszernego listu lub zwięzłego dokumentu. Pewne zaskoczenie wywołał fakt przyniesienia do stolika kawiarni Państwowego Instytutu Wydawniczego gotowego tekstu przez Antoniego Słonimskiego. Było to prawdopodobnie na początku marca 1964 r. Z badań Łukasza Garbala wynika, że dokument przyniesiony przez Antoniego Słonimskiego nie zawierał ostatecznej treści Listu $34^{5}$. Wersja prawdopodobnie tożsama z tekstem złożonym w Urzędzie Rady Ministrów brzmi następująco:

Ograniczenie przydziału papieru na druk książek i czasopism oraz zaostrzenie cenzury prasowej stwarza sytuację zagrażającą rozwojowi kultury narodowej. Niżej podpisani, uznając istnienie opinii publicznej, prawa do krytyki, swobodnej dyskusji i rzetelnej informacji za konieczny element postępu, powodowani troską obywatelską, domagają się zmiany polskiej polityki kulturalnej $w$ duchu praw zagwarantowanych przez Konstytucję Państwa Polskiego i zgodnych $\mathrm{z}$ dobrem narodu $\mathrm{u}^{6}$.

Od momentu pojawienia się tekstu rozpoczęła się dyskusja o zbieraniu sygnatariuszy. Antoni Słonimski starał się pozyskać nie tylko literatów, spotykających się przy kawiarnianym stoliku, ale też ludzi ze świata nauki, m.in. Leopolda Infelda czy Tadeusza Kotarbińskiego ${ }^{7}$. Paweł Hertz z kolei przyczynił się do poszerzenia listy o przedstawicieli prawicy - Stanisława Cata-Mackiewicza, Stefana Kisielewskiego i Jerzego Turowicza. Jan Józef Lipski natomiast zebrał podpisy od m.in. Marii Dąbrowskiej, Anny Kowalskiej czy Karola Estreichera. Ostateczna lista sygnatariuszy wyglądała następująco:

Leopold Infeld,

Maria Dąbrowska,

Antoni Słonimski,

Paweł Jasienica,
Konrad Górski, Maria Ossowska, Kazimierz Wyka, Tadeusz Kotarbiński,

${ }^{4}$ Vide: szerzej: E. Beynar-Czeczott, Mój ojciec Paweł Jasienica, Warszawa 2006, s. 94-95; Informacja dyrektora Departamentu III MSW płk. Stanisława Filipiaka dotyczaca rozszerzonego zebrania plenarnego ZG ZLP w dniach 17-18 stycznia 1964 roku w Warszawie, 23 I 1964, [w:] Marzec 1968 w dokumentach MSW, t. 1, Niepokorni, Warszawa 2008, s. 145; A. Kowalska, Dzienniki 1927-1969, przedm. J. Hartwig, wyb. P. Kądziela, Warszawa 2008, s. 377-378 [zapis z 20.01.1964]; M. Dąbrowska, Dzienniki 1914-1965 w 13 tomach, t. 13: 1962-1965, Warszawa 2009, s. 164 [zapis z 31.01.1964].

5 Vide: Ł. Garbal, Jak powstawał List 34, „Wolność i Solidarność” 2012, nr 4, s. 31-35.

${ }^{6}$ Ibidem, s. 33.

${ }^{7}$ E. Beynar-Czeczott, op. cit., s. 97. 
Karol Estreicher,

Stanisław Pigoń,

Jerzy Turowicz,

Anna Kowalska,

Mieczysław Jastrun,

Jerzy Andrzejewski,

Adolf Rudnicki,

Paweł Hertz,

Stanisław Mackiewicz,

Stefan Kisielewski,

Jan Parandowski,

Zofia Kossak,

Jerzy Zagórski,
Jan Kott,

Wacław Sierpiński,

Kazimierz Kumaniecki,

Artur Sandauer,

Władysław Tatarkiewicz,

Edward Lipiński,

Stanisław Dygat,

Adam Ważyk,

Marian Falski,

Melchior Wańkowicz,

Jana Szczepański,

Aleksander Gieysztor,

Julian Krzyżanowski

Dokument z 34 nazwiskami przedstawicieli literatury i nauki 14 marca 1964 r. trafił do kancelarii Prezesa Rady Ministrów Józefa Cyrankiewicza. Jednocześnie odpisy zaczęły być rozpowszechniane w środowisku warszawskim, prawdopodobnie za cichym pozwoleniem Antoniego Słonimskiego. Złożenie dokumentu $\mathrm{w}$ kancelarii premiera to jednak dopiero początek sprawy Listu 34 - miała ona szeroki oddźwięk zarówno w kraju, jak i za granicą.

Początkowo władze zareagowały aresztowaniem Jana Józefa Lipskiego, który po dwóch dniach został jednak wypuszczony. Informacje o proteście zaczęły być jednak przekazywane na Zachód - 26 marca powiadomiła o nim Agencja Reutera, później powtórzono to na antenie Rozgłośni Polskiej Radia Wolna Europa. Zaczęto o nim również pisać w zagranicznej prasie. Wywołało to gwałtowną reakcję władz partyjnych. Już 26 marca wydano zarządzenie o zakazie ogłaszania tekstów i wymieniania nazwisk dwunastu pisarzy, w tym m.in. Antoniego Słonimskiego, Jerzego Andrzejewskiego oraz Melchiora Wańkowicza ${ }^{8}$. Od początku dało się zauważyć pewne zróżnicowanie polityki wobec podpisanych pod protestem osób. Miało to prawdopodobnie na celu ich podzielenie i „przeciągnięcie” części na swoją stronę, co, jak się później okazało, przyniosło pewne efekty. Kolejnym krokiem władz była odmowa wydania paszportu części sygnatariuszy oraz odebranie Arturowi Sandauerowi tego, który posiadał. Ukarano także "Tygodnik Powszechny” za podpis Jerzego Turowicza, administracyjnie zmniejszając nakład z 40 do 30 tysięcy. W prasie krajowej rozpętała się kampania przeciw postulatom Listu 34, prowadzona głównie przez warszawską „Kulturę” oraz w mniejszym stopniu „Politykę”.

\footnotetext{
${ }^{8}$ A. Garlicki, Naiwniacy i cwaniacy?, „Polityka” 5.03.1994, nr 10, s. 1.
} 
Jerzy Zawieyski, ówczesny poseł z ramienia Znaku, ale też członek ZLP, spotkał się z Antonim Słonimskim i Janem Józefem Lipskim na początku kwietnia i zaproponował im, że spróbuje pośredniczyć w ich sprawie u premiera. Zanotował, że obydwaj mężczyźni byli zdumieni reakcją rządu i chętnie przystali na jego propozycję. Pisarzowi udało się jednak jedynie spotkać z wiceministrem kultury i sztuki Kazimierzem Rusinkiem, który wyjaśnił mu powód represji - rozpowszechnianie tekstu protestu i jego dotarcie do zachodnich ambasad. Pokazał także listy przeciwko zagranicznemu kolportażowi podpisane przez Jana Parandowskiego, Tadeusza Kotarbińskiego, Kazimierza Wykę i siedem innych osób ${ }^{9}$. Wynikałoby z tego, że już pod koniec marca dziesięciu sygnatariuszy Listu 34 wyraziło niezadowolenie z przesłania go na Zachód. Jerzy Zawieyski z rozmowy wywnioskował, że władza cofnie represje wobec osób, które wyślą podobne listy do premiera. Nie udało mu się jednak doprowadzić do spotkania z Józefem Cyrankiewiczem, na którym przedstawiłby postulaty sygnatariuszy. Z Kazimierzem Rusinkiem pisarz widział się jeszcze 19 kwietnia i podjął wtedy temat sankcji nałożonych na „Tygodnik Powszechny”. Wiceminister przekazał warunki postawione przez premiera: [...] niech zmieniq Turowicza, nakład będzie przywrócony $^{10}$. Na to rzecz jasna nikt nie mógł się zgodzić, interwencje Jerzego Zawieyskiego pozostały więc bezowocne.

8 kwietnia premier Cyrankiewicz postanowił spotkać się z częścią sygnatariuszy ${ }^{11}$. Według wspomnień Jerzego Putramenta:

Towarzystwo dobrano według klucza bardzo pokrętnego. Nie było szeregu podpisywaczów, było zaś paru, którzy niczego nie podpisali, wprost przeciwnie - np. Schaff i ja, było sporo profesorów i trochę literatów $w^{12}$.

Józef Cyrankiewicz zarzucił sygnatariuszom niechęć do spotkania z nim i niewłaściwość protestu. Uczestniczący w zebraniu literaci, m.in. Jerzy Andrzejewski, Anna Kowalska, Stanisław Dygat czy Jan Parandowski, bronili treści dokumentu. Premier ripostował, że cenzura występuje na całym świecie, potępił przekazanie protestu na Zachód oraz chciał skłonić zebranych do wycofania podpisów, czego nie uczynili. Julian Przyboś natomiast stwierdził, że nigdy nie podpisałby podobnego dokumentu, o co nikt go nie prosił, oraz zaatakował nieobecnego Antoniego Słonimskiego, mówiąc że jest kiepskim poetą ${ }^{13}$. Na taką ocenę odpowiedź miał sam premier, stwierdzając: Ale

\footnotetext{
${ }^{9}$ J. Zawieyski, Dzienniki, t. 2, 1960-1969, Warszawa 2012, s. 385 [zapis z 2.04.1964].

${ }_{10}$ Ibidem, s. 391 [zapis z 19.04.1964].

11 Vide: szerzej: A. Kowalska, op. cit., s. 383-386 [zapis z 13.04.1964].

12 J. Putrament, Pół wieku. Natasza (nowa wersja Rapanui), Warszawa 1978, s. 317.

${ }^{13}$ M. Jastrun, Dziennik 1955-1981, Kraków 2002, s. 424 [zapis z 30.06.1964].
} 
przyzna pan, że dobry felietonista ${ }^{14}$, co było aluzją do tekstów, w których autor kpił m.in. właśnie z Juliana Przybosia. Na koniec Józef Cyrankiewicz pokazał listy napisane do niego przez kilku sygnatariuszy - wśród nich było dwóch literatów - Jan Parandowski i Artur Sandauer. Nie przekreślały one słuszności protestu, a jedynie potępiały przekazanie go na Zachód. Postępowanie premiera miało prawdopodobnie na celu udowodnienie, że możliwe jest jeszcze odkupienie "winy" i opowiedzenie się po stronie Partii.

Władza wciąż dążyła jednak do skompromitowania idei Listu 34. Okazja nadarzyła się po opublikowaniu 18 kwietnia w londyńskim „Timesie” listu 21 brytyjskich intelektualistów protestujących przeciw łamaniu wolności słowa w Polsce. Literaci, mimo namów przedstawiciela partyjnego skrzydła ZLP Jerzego Putramenta, odmówili podpisania odpowiedzi władz polskich. Poparła go natomiast część profesorów i 28 kwietnia na łamach „Timesa” ukazał się List 10, który zaprzeczał istnieniu represji wobec literatów.

Nie wystarczył on jednak do przekonania mediów zachodnich o istnieniu swobody słowa w PRL i wywołał ich gwałtowne reakcje. Władza postanowiła więc, że muszą ją poprzeć literaci. Na spotkaniu ZLP 22 kwietnia ustalono, że należy opracować spis pisarzy, którzy byliby skłonni poprzeć protest przeciw prowokacjom pism zachodnich. Ostateczny tekst dokumentu mówił o zorganizowanej kampanii oczerniającej Polskę Ludową i sprzeciwie wobec ingerencji zagranicy w polską politykę kulturalną ${ }^{15}$. Podczas zbierania podpisów ujawniły się różne postawy wobec sprawy Listu 34. Nie wszyscy sygnatariusze kontrlistu to osoby popierające politykę Partii - podpisy zbierano nie zawsze zgodnie z prawem, np. członków prowincjonalnych oddziałów wpisywano hurtowo. Kierownictwo związku wywierało szczególny nacisk na literatów związanych z powstaniem Listu 34 - Anna Kowalska zapamiętała, że do podpisania kontrlistu nakłaniali Stefan Żółkiewski i Jerzy Putrament ${ }^{16}$. Dokument był wyłożony na stoliku w siedzibie organizacji, a pisarze partyjni w razie niepodpisania byli wzywani na rozmowy do Komitetu Warszawskiego PZPR. W większości przypadków nie przyniosły one oczekiwanego skutku, jedynie pięcioro niezbyt popularnych literatów przyłączyło się po nich do

14 Ibidem.

15 „My, niżej podpisani pisarze polscy, wyrażamy stanowczy protest przeciwko uprawianej na łamach prasy zachodniej oraz na falach dywersyjnej rozgłośni radiowej »Wolnej Europy«, zorganizowanej kampanii oczerniającej Polskę Ludową. Sprzeciwiamy się obcej ingerencji w nasze problemy wewnętrzne, w naszą politykę kulturalną, która jest wspólną sprawą inteligencji twórczej oraz kierownictwa politycznego i państwowego kraju”. List Trzydziestu Czterech. Głosy i komentarze, oprac. J. Krzeczkowski, Londyn 1964, s. 95.

16 A. Kowalska, op. cit., s. 389 [zapis z: 29.04.1964]. 
kontrlistu ${ }^{17}$. Ujawniła się także grupa pisarzy, którzy nie podpisali Listu 34, bo nie zostali o to poproszeni, ale zgadzali się z jego ideą. Jerzy Zawieyski wspominał, że po powrocie z Paryża zastał w domu wezwanie egzekutywy POP, aby składać podpisy protestacyjne przeciwko Wolnej Europie w zwiq̨zku $z$ manifestem 34 intelektualistów ${ }^{18}$, które niewiele myśląc, wyrzucił do kosza. 9 maja Podstawowa Organizacja Partyjna Oddziału Warszawskiego ZLP (POP OW ZLP) opublikowała apel do członków o podpisanie kontrlistu. Wyrażano chęć mobilizacji przeciwko atakom Zachodu na PRL i zawarto informację o ilości zebranych już nazwisk sygnatariuszy. Zygmunt Mycielski, kompozytor, ale też pisarz, nie rozumiał motywów zachowania osób popierających kontrlist, często jego znajomych. Pisał:

Parę osób tu przychodziło mi się... żalić, że podpisali, Żałosne to. Sporo osób nie podpisało. Ale małość przeważa. Jeden się boi o miejsce, o prawa autorskie, o - nie wiem już co. Każdy się boi. Tak jak się boją spotkać za granicą z Giedroyciem, Czapskim czy Jeleńskim. A nuż nie dostaną paszportu? Rozumiem jeszcze młodych, ale starzy, którzy się już najeździli? Nie wymagam bohaterstwa, ale żeby tylu ludzi nie dbało - już choćby tylko o jakiś własny... styl? ${ }^{19}$.

Kontrlist opatrzony 157 podpisami został opublikowany 10 maja w „Życiu Warszawy". Zbiórka trwała jednak nadal - przez kilka tygodni udało się pozyskać około 600 z 1000 członków ZLP. Nie znalazło się tam jednak nazwisko żadnego z sygnatariuszy Listu 34, a także 57 pisarzy partyjnych. Należący do PZPR Tadeusz Konwicki odciął się od kontrlistu, a gdy został w tej sprawie wezwany do Komitetu Warszawskiego, „wykręcił się” oświadczeniem, że jest poniżej jego honoru polemizować z »Wolnq Europq «²0. Marian Brandys z kolei w piśmie do egzekutywy POP OW ZLP uzasadnił odmowę tym, że sama jego działalność świadczy o postawie wobec zachodniej propagandy. Oświadczył także:

[...] wyczuwam w niej [deklaracji, kontrliście - A.C.] ostrze skierowane przeciwko kilku wybitnym pisarzom polskim, których głęboko szanuję i od których uczyłem się pisać ${ }^{21}$.

17 K. Rokicki, Literaci. Relacje między literatami a władzami PRL w latach 1956-1970, Warszawa 2011, s. 293.

${ }^{18}$ J. Zawieyski, op. cit., s. 395-396 [zapis z: 18.05.1964].

19 Z. Mycielski, Dziennik 1960-1969, Warszawa 2001, s. 234-235 [zapis z: 24.06.1964].

20 Ibidem, s. 19.

${ }^{21}$ J. Kuciel-Frydryszak, op. cit., s. 253. 
Do związku napływało więcej takich wyjaśnień. Krótko i dobitnie, w telegraficznej formie, wyłożył swoje racje Antoni Madej: Protestu nie podpiszę. Nie należy robić z ludzi poważnych głupców. Nie należy robić z Polski getta kulturalnego ani politycznego ${ }^{22}$. Wiktor Woroszylski podkreślił, że akcja wywiera wyłącznie negatywny wpływ i nie wyraża autentycznych nastrojów wśród pisarzy, a Andrzej Kijowski oświadczył, że odwraca ona uwagę od rzeczywistych problemów w życiu kulturalnym ${ }^{23}$. Literaci zarzucali też kontrlistowi plebiscytowy charakter czy nieskonsultowanie jego treści z członkami ZLP. Nawet mniej znani pisarze wskazywali na błędy w polityce kulturalnej PZPR. [...] korzystając z okazji zapytuję uprzejmie, co PT Egzekutywa uczyniła, aby w Polsce została zniesiona szalejąca od dziewiętnastu lat cenzura? ${ }^{24}$ - pytał twórca literatury dziecięcej Juliusz Kędziora. Kontrlist był jasnym wezwaniem do opowiedzenia się po konkretnej stronie konfliktu i tak traktowały go władze. W opracowaniach Ministerstwa Spraw Wewnętrznych możemy przeczytać, że dokonał się

[...] jak gdyby rozłam ideowy na terenie Związku Literatów poprzez konieczność ujawnienia swego stanowiska w sensie akcesu lub dezaprobaty aktualnej polityki kulturalnej w kraju ${ }^{25}$.

Podpisani przybierali jednak później różne postawy, nie był to więc stanowczy wybór strony partyjnej, a raczej wyraz niechęci do angażowania się w konflikt. Często podkreślali, że nie protestują przeciwko sygnatariuszom Listu 34, a tylko przeciw reakcji zachodnich mediów. Wśród podpisanych pod kontrlistem przeważały nazwiska mało popularnych, często prowincjonalnych pisarzy - Maria Dąbrowska złośliwie zauważyła:

Nam wypominają Cat-Mackiewicza, a sami korzystają z podpisu wszystkich OeNeRowców, hrabiów, b. ziemian (Alfred Łaszowski, Al. Bocheński, Morstin) ${ }^{26}$.

Zdarzały się jednak także należące do literatów chętnie czytanych wówczas i później. Do nich można zaliczyć m.in.: Jana Brzechwę, Romana Bratnego, Alinę i Czesława Centkiewiczów, Jarosława Iwaszkiewicza, Wisławę Szymborską czy Alfreda Szklarskiego.

${ }^{22}$ K. Rokicki, op. cit., s. 288-289.

${ }^{23}$ Ibidem, s. 289.

${ }^{24}$ Ibidem, s. 290.

${ }^{25}$ Informacja dotycząca zachowania się grupy literatów skupionej wokół A. Słonimskiego i S. Staszewskiego, 30 V 1964 r., cyt. za: K. Rokicki, Sprawa Listu 34 w materiałach MSW, „Polska 1944/1945-1989. Studia i materiały" 2005, t. 7, s. 215.

${ }^{26}$ M. Dąbrowska, op. cit., s. 199 [zapis z: 14.05.1964]. 
Kontrlistu nie podpisał żaden z trzydziestu czterech, a w końcu z przedstawicielami pisarzy postanowił się spotkać Władysław Gomułka. 4 maja odbyło się zebranie, w którym oprócz niego wzięło udział prezydium ZG ZLP, w tym przewodniczący Jarosław Iwaszkiewicz. Podkreślił on brak udziału zarządu w powstaniu Listu 34 i odciął się od niego, ale jednocześnie poruszył problem braku papieru, potrzebę dwóch nowych pism literackich, uregulowania sytuacji prawnej literatów oraz poprosił o ponowne przemyślenie sprawy sankcji nałożonych na pisarzy, ponieważ kształtują one niekorzystny obraz PRL za granicą. Jak widać, Jarosław Iwaszkiewicz próbował w pewien sposób pomóc sygnatariuszom, choć nie poparł ich działania. Jego postępowanie od momentu dowiedzenia się o powstaniu protestu można uznać za dyskusyjne. Został poinformowany już 17 marca przez Jerzego Putramenta, który zanotował, że rozmówca jest oburzony na tę inicjatywę ${ }^{27}$. Widocznie zmęczony i przestraszony - uciekł do Włoch, skąd wrócił dopiero 24 kwietnia. 29 marca zdobył się jednak na napisanie listu do ministra kultury i sztuki Tadeusza Galińskiego, w którym zaprotestował przeciwko nałożeniu zakazu druku na kilkunastu pisarzy pomimo wcześniejszej obietnicy, że [...] nie będq wyciagane żadne konsekwencje z idiotycznego kroku poważnych bądź co bq̨dź $l u d z i^{28}$. Zapiski w dzienniku Jarosława Iwaszkiewicza ujawniają, że był on załamany postawą członków ZLP, a powstanie memoriału odczuł jako osobistą porażkę. W prywatnych notatkach nie ukrywał opinii o sygnatariuszach zarówno Listu 34 (biedna Maryjka w tym wszystkim - i ten idiota skończony Jaś [Parandowski] - i ta największa kanalia wśród pisarzy, »moralista z własnej nominacji« Andrzejewski [...]. Antoni głupi, ale zawsze jednakowy [...] ${ }^{29}$ ), jak i listu 10 profesorów (podwinęli ogony jak psi i wycofujq się, a co szkody narobili, to narobili ${ }^{30}$ ). Krytykował równocześnie drugą stronę, partyjnych durni $^{31}$, którzy pozwolili na rozdmuchanie afery. Swoje stanowisko przewodniczący przedstawił na posiedzeniu ZG ZLP, które odbyło się 7 maja. Powiedział, że sygnatariusze Listu 34 nie działali w porozumieniu z kierownictwem zrzeszenia pisarzy i głównym celem będzie teraz usunięcie ZLP ze sceny politycznych rozgrywek. Jednocześnie podkreślił, że zarząd ma obowiązek bronić wszystkich członków związku. 17 maja w „Życiu Warszawy” ukazał się jednak wywiad z Jarosławem Iwaszkiewiczem, który mówił o problemach materialnych pisarzy, ale winą za opóźnienia w rozmowach

27 J. Putrament, op. cit., s. 316.

28 A. Garlicki, op. cit., s. 7.

29 J. Iwaszkiewicz, Dzienniki 1964-1980, oprac. A. i R. Papiescy, R. Romaniuk, wstęp A. Gronczewski, Warszawa 2011, s. 55 [zapis z: 21.04.1964].

30 Ibidem, s. 54 [zapis z: 21.04.1964].

31 Ibidem. 
z władzą obarczał sprawę Listu 34 i potępił ten protest, nazywając go heca antypolskq ${ }^{32}$. Podkreślił, że po rozmowie ZG ZLP z Władysławem Gomułką przydział papieru zaczął być zwiększany, a reszta wyrażonych tam postulatów jest rozpatrywana, co świadczy o trosce, jaką Partia otacza literaturę ${ }^{33}$. Środowisko pisarskie było oburzone, Maria Dąbrowska skomentowała:

Doszedł do wniosku, że może sobie pozwolić na wszelką bezczelność i to bezkarnie - A ten człowiek miał taką piękną szansę. Mógł był odrazu naprawić swoją reputację w społeczeństwie - zrehabilitować się jako Prezes. Wolał się zbłaźnić - idzie mu tylko o łaskę rządu i partji ${ }^{34}$.

Jak wynika z doniesień MSW, Jarosław Iwaszkiewicz swoim postępowaniem wywoływał coraz większą niechęć w środowisku:

w swym lojalizmie zabrnął tak daleko, że jego własna rodzina ma $\mathrm{z}$ tego powodu wątpliwości. [...] Jarosław co dzień dostaje obelżywe listy (bynajmniej nie anonimy, np. prof. Lipiński napisał mu expressis verbis, że jest »zakałą literatury «) i chodzi z miną ofiary ${ }^{35}$.

Z dziennika pisarza wynika, że chciał załagodzić konflikt, ale niektóre podjęte przez niego działania trudno brać za zmierzające do tego celu.

Sygnatariusze Listu 34 postanowili zaprotestować przeciw sankcjom, a Maria Dąbrowska otrzymała zadanie napisania tekstu wystąpienia wygłoszonego na walnym zebraniu OW ZLP 12 czerwca. Jerzy Zawieyski, który poprowadził zebranie i czytał przemówienie kilka dni przed jego wygłoszeniem, określił je jako wielkie dzieło, napisane znakomicie, polemiczne i patetyczne zarazem ${ }^{36}$. Na początku pisarka przedstawiła treść Listu 34 i poinformowała o okolicznościach jego złożenia, a także o tym, że do tej pory nie udało się uzyskać odpowiedzi. Zreferowała sprawę aresztowania Jana Józefa Lipskiego i szczegółowo wymieniła represje stosowane przez władzę wobec pisarzy, uznając je za błędne posunięcie:

Zamknąć niemal całkowicie usta ludziom, co się domagają większej swobody wypowiedzi i za to, że się jej domagają - to nie wykazuje zbędności Listu do premiera, lecz raczej potwierdza jego wagę $[\ldots]^{37}$.

${ }^{32}$ List Trzydziestu Czterech. Głosy i komentarze, op. cit., s. 107.

${ }^{33}$ Ibidem, s. 108.

34 M. Dąbrowska, op. cit., s. 200 [zapis z: 17.05.1964].

35 Notatka z materiałów Biura W z dnia 2 czerwca 1964 r., cyt. za: K. Rokicki, Sprawa Listu 34 ..., s. 217.

${ }^{36}$ J. Zawieyski, op. cit., s. 398 [zapis z: 9.06.1964].

37 Przemówienia Marii Dąbrowskiej wygłoszone 12 VI 1964 r. na zebraniu Warszawskiego Oddziału ZLP (stenogram autoryzowany), cyt. za: A. Garlicki, op. cit., s. 9. 
Przedstawiła zarzuty wobec memoriału i punkt po punkcie je odparła. Jednocześnie zwróciła uwagę na kampanię prasową przeciwko Listowi 34, wymieniając obraźliwe epitety, jakimi obrzucano sygnatariuszy. Zauważyła też łatwość, z jaką strąca się z piedestału ludzi wcześniej poważanych:

Ale jak długo jest się autorytetem? Tylko dopóki »autorytet« nie wyrazi zdania albo życzenia, które nie spodoba się środowisku, co go za autorytet uznało $^{38}$.

Stwierdziła, że cała sprawa została źle rozegrana przez władze - gdyby nie pojawiły się represje, a treść protestu została oficjalnie ogłoszona, to zapewne nie wywołałaby skandalu. Kolejnym błędem było wysłanie kontrlistu, który został wykorzystany przez Radio Wolna Europa jako dowód na ograniczanie swobody słowa w Polsce. Maria Dąbrowska skrytykowała postępowanie Jarosława Iwaszkiewicza, który jako prezes ZLP nie próbował być rozjemcą, a opowiedział się przeciwko sygnatariuszom Listu 34. Na koniec poprosiła o zniesienie represji oraz wyraziła nadzieję, że w ciągu spotkania dojdzie do porozumienia władzy i pisarzy. Całe przemówienie miało duży walor informacyjny - Maria Dąbrowska uporządkowała dzieje protestu od marca do czerwca 1964 r., dzięki czemu zebrani zyskali całościowy ogląd sytuacji. Wystąpienie zostało ocenione bardzo wysoko, choć pisarka nie była z niego zadowolona. Ciężko wówczas chorowała, a przemówienie na czerwcowym zebraniu było ostatnim w jej karierze. Sprawa Listu 34 męczyła ją już, żałowała, że go podpisała, a jednocześnie poczucie obowiązku nie pozwalało jej na odwołanie tej decyzji. Po pisarce głos zabrał Jerzy Putrament, broniący kontrlistu, którego celem, jak sam twierdził, nie miał być atak na pisarzy podpisanych pod Listem 34, lecz działanie przeciwko wrogiej propagandzie. Jego przemówienie zostało dobrze przyjęte przez samych sygnatariuszy - Maria Dąbrowska wspominała, że mówił b. dobrze, lojalnie, nie można mu ani słowa zarzucićc ${ }^{9}$. Kolejny przedstawiciel ZG ZLP, Jarosław Iwaszkiewicz, odniósł się do referatu pisarki - nie sprzeciwił się krytyce, ale stwierdził: nie przyjmuję tylko jednej rzeczy - braku szacunku dla mojego wysiłku ${ }^{40}$. Marii Dąbrowskiej nie wzruszyło jego litowanie się nad sobq, określiła go jako szatana sentymentalnego $o^{41}$. Kolejnym przemawiającym, wbrew wcześniejszym ustaleniom sygnatariuszy, był Stanisław Cat-Mackiewicz - mówił on m.in. o cenzurze, porównując ją z morfiną, która przez pewien czas przynosi

\footnotetext{
${ }^{38}$ Ibidem, s. 10.

39 M. Dąbrowska, op. cit., s. 210 [zapis z 15.06.1964].

${ }^{40}$ K. Rokicki, Literaci..., s. 299.

${ }^{41}$ M. Dąbrowska, op. cit., s. 210 [zapis z 15.06.1964].
} 
ulgę, używana stale jest środkiem niekorzystnym ${ }^{42}$. Rozpętała się dyskusja, w trakcie której stronę władzy reprezentował Kazimierz Koźniewski. Najpierw, bez podawania argumentów, skrytykował całość pierwszego wystąpienia, a następnie zarzucił Pawłowi Jasienicy współpracę z UB, co oburzyło większość obecnych na sali. Marii Dąbrowskiej przypominało to identyczne delatorskie przemówienia z najgorszych czasów Stalinowskich ${ }^{43}$. W swojej obronie przemawiało jeszcze kilku sygnatariuszy Listu 34, m.in. Melchior Wańkowicz i Stefan Kisielewski, ale nie udało się wypracować żadnego wspólnego stanowiska ZLP, a zebranie zakończono w atmosferze kłótni. Prowadzący Jerzy Zawieyski, oburzony coraz częściej padającymi niecenzuralnymi słowami, nie mogąc doprosić się o spokój, przerwał spotkanie. Najlepiej zapamiętane zostało właśnie przemówienie Marii Dąbrowskiej. Jeden z obecnych na sali, Andrzej Kijowski, tak opisał jego znaczenie:

Zawierało ono historię "sprawy 34«, którą wszyscy znają, oraz opinie, które od dwóch miesięcy znajdują się w powszechnym obiegu. Wartość przemówienia polegała na dokładności w zestawieniu faktów oraz na jasności i precyzyjności w komentarzach. Cała historia nabrała naraz godności, wszyscyśmy się w naszych własnych oczach podnieśli, gdy nam o nas samych dokładnie, chłodno i spokojnie opowiedziano. Dąbrowska w swoim referacie nie odkryła nic nowego w sprawie, którą znamy, i w nas samych. Odkryła po prostu sekret literatury, tj, porządek estetyczno-moralny skryty pod tym całym bałaganem plotki i głupstwa ${ }^{44}$.

Napięcia pomiędzy stronnictwem propartyjnym i opozycyjnym w ZLP ujawniły się również na ostatnim zebraniu, na którym poruszono sprawę Listu 34. Odbyło się ono 5 października 1964 r., a referat w imieniu władzy przedstawił Zenon Kliszko. Potem głos zabrał Antoni Słonimski, który jasno określił swoje położenie:

Ja jestem stroną słabą. Ja nie mam armii, UB, Ministerstwa Spraw Wewnętrznych, policji. Z mną stoją tylko moje słowa i kilkadziesiąt lat mojej działalności jako pisarza i człowieka ${ }^{45}$.

Pomimo że władza nie zaprezentowała się dobrze na zebraniu 5 października, a większość uczestników była wyraźnie po stronie sygnatariuszy Listu 34, to przemówienie Zenona Kliszki mogłoby być ostatnim akcentem

42 T. Jastrun, op. cit., s. 22.

${ }^{43}$ M. Dąbrowska, op. cit., s. 211 [zapis z 15.06.1964].

${ }^{44}$ A. Kijowski, Dziennik 1955-1969, oprac. K. Kijowska i J. Błoński, Kraków 1998, s. 197 [zapis z 14.06.1964].

${ }_{45}$ Przebieg dyskusji na otwartym zebraniu POP PZPR ZLP, 5 X 1964, [w:] Marzec 1968 w dokumentach MSW..., op. cit., s. 188. 
w sprawie protestu intelektualistów. Tak się jednak nie stało, ponieważ tego samego dnia aresztowano Melchiora Wańkowicza, oskarżając go o kontakty z Wolną Europą. Skazano go na trzy lata więzienia, lecz karę uchylono ze względu na poważny wiek pisarza. Środowisko literackie było oburzone - Antoni Słonimski twierdził:

To nie było skierowane przeciwko Wańkowiczowi, to biło w całą naszą grupę pisarzy, którzy mają swoje zdanie i inaczej komentują pewne zjawiska polityczne i społeczne. [...] Wyrok i proces miał na celu zastraszenie nas ${ }^{46}$.

Anna Kowalska wyrażała zdziwienie tym, że do roli „męczennika” wybrano właśnie tego pisarza, ponieważ był on znany z wypowiedzi prorządowych. Według doniesień bezpieki, badającej reakcje na proces, literaci uważali go za błąd polityczny - Melchior Wańkowicz wyrósł na wieszcza narodowego, a aresztowanie tylko przysporzyło mu popularności. Maria Dąbrowska zauważyła, że było to ponowne i niepotrzebne poruszenie sprawy Listu 34. Obawiała się też, że to dopiero początek nowej kampanii przeciw sygnatariuszom, których władze będą chciały oczernić. Aresztowany pisarz wcześniej nie cieszył się najlepszą opinią w środowisku, a po procesie jego pozycja umocniła się. Władze nie odniosły przy tym żadnych korzyści, a jedynie się skompromitowały, uchylając prawomocny wyrok i pozwalając na uwolnienie literata.

W dokumentach MSW znajdują się również informacje o odbiorze Listu 34 przez środowisko pisarskie. Odnotowano dużo opinii negatywnych - protest uważano za zorganizowaną akcję grupy Antoniego Słonimskiego, mającą na celu skompromitowanie ZLP i niedopuszczenie do rozmów z władzą. Pojawiła się także krytyka represji, które zastosowano wobec sygnatariuszy listu stwierdzającego tylko obecny stan kultury. Donoszono również o wyśmiewaniu protestu, nazywanego aferq 34 leśnych dziadków ${ }^{47}$. Zazwyczaj jednak sama treść listu była aprobowana, a potępiano przekazanie go za granicę. Należy pamiętać, że informacje często były zbierane przez MSW w sposób wybiórczy - to wyjaśnia dużą ilość reakcji negatywnych. Inaczej jednak przedstawiało się to np. podczas zebrań ZLP - przemówienie Marii Dąbrowskiej z 12 czerwca zyskało szeroką aprobatę, a głosy krytyki pochodziły tylko od pisarzy blisko związanych z władzą. Wydaje się, że solidarność przedstawicieli środowiska z sygnatariuszami Listu 34 była częstsza niż głosy potępienia. Dowodziły tego również odmowy podpisów pod

${ }^{46}$ Doniesienie „Ewy” z 12 XI 1964 r., cyt. za: K. Rokicki, Literaci..., s. 309.

47 Informacja o reperkusjach $w$ zwiq̨zku $z$ memoriałem grupy polskich literatów i naukowców, 18 IV 1964 r., cyt. za: K. Rokicki, Sprawa Listu 34..., s. 213. 
kontrlistem. Jednocześnie funkcjonowała grupa pisarzy podporządkowanych Partii, którzy go podpisali, wspierali kampanię prasową przeciw zachodniej ingerencji w sprawy Polski oraz spierali się z sygnatariuszami memoriału na zebraniach ZLP. Szczególna rola przypadła Jarosławowi Iwaszkiewiczowi stojącemu na czele tej organizacji, który próbował przekonać władzę o braku potrzeby represji, a jednocześnie odcinał się od Listu 34. Była również grupa sygnatariuszy, którzy pomimo sankcji nie odwołali podpisów i bronili idei protestu, choć jak Maria Dąbrowska uważali, że rządzący niepotrzebnie wracają do tej sprawy i sami sobie szkodzą, rozdmuchując ją. Sprawa memoriału z 1964 r. była więc kolejnym etapem podziału pisarzy na dwa obozy: związanych z władzą i wyrażających sprzeciw. Kulminacja nastąpiła w 1968 r., jednak sprawę Listu 34 można uznać za zapowiedź protestu obejmującego szerszą grupę intelektualistów.

\section{BIBLIOGRAFIA}

\section{Źródła}

Beynar-Czeczott E., Mój ojciec Paweł Jasienica, Warszawa 2006.

Dąbrowska M., Dzienniki 1914-1965 w 13 tomach, t. 13, 1962-1965, Warszawa 2009.

Estreicher K. jr, Dziennik wypadków, t. 2, Kraków 2002.

Garlicki A., Naiwniacy i cwaniacy?, „Polityka” 1994, nr 10, s. 7-12.

Iwaszkiewicz J., Dzienniki 1964-1980, oprac. A. i R. Papiescy, R. Romaniuk, wstęp A. Gronczewski, Warszawa 2011.

Jastrun M., Dziennik 1955-1981, Kraków 2002.

Kijowski A., Dziennik 1955-1969, oprac. K. Kijowska i J. Błoński, Kraków 1998.

Kowalska A., Dzienniki 1927-1969, przedm. J. Hartwig, wyb. P. Kądziela, Warszawa 2008.

List Trzydziestu Czterech. Głosy i komentarze, oprac. J. Krzeczkowski, Londyn 1964.

Marzec 1968 w dokumentach MSW, t. 1: Niepokorni, Warszawa 2008.

Mycielski Z., Dziennik 1960-1969, Warszawa 2001.

Putrament J., Pół wieku. Natasza (nowa wersja Rapanui), Warszawa 1978.

Zawieyski J., Dzienniki, t. 2, 1960-1969, Warszawa 2012.

\section{Opracowania}

Bikont A., Szczęsna J., Lawina i kamienie. Pisarze wobec komunizmu, Warszawa 2006.

Eisler J., List 34, Warszawa 1993. 
Garbal Ł., Jak powstawał List 34, „Wolność i Solidarność”2012, nr 4, s. 25-50.

Jan Józef Lipski - spotkania i spojrzenia: ksiq̨żka o Janie Józefie Lipskim, red. A. Brodzka, Warszawa 1996.

Jastrun T., Mysz, która ryknęła, „Res Publica Nowa” 1994, nr 3, s. 4-12; 1994, nr 4, s. 17-25.

Kuciel-Frydryszak J., Słonimski. Heretyk na ambonie, Warszawa 2012.

Rokicki K., Literaci. Relacje między literatami a władzami PRL w latach 1956-1970, Warszawa 2011.

Rokicki K., Sprawa Listu 34 w materiałach MSW, „Polska 1944/1945-1989. Studia i materiały” 2005, t. 7, s. 197-221.

Synoradzka A., Andrzejewski, Kraków 1997.

Woźniakowski K., Między ubezwłasnowolnieniem a opozycją. Zwiq̨zek Literatów Polskich w latach 1949-1959, Kraków 1990.

Aleksandra Czyż

\section{FROM RESISTANCE TO OPPORTUNISM - THE WRITERS' ATTITUDES TOWARD THE LETTER OF 34}

$\mathrm{T}$

he Letter of 34 was the protest of Polish writers and scientists against the Polish

United Worker' Party cultural politic, which was conveyed to the authorities on March 1964. This document provoked a strong reaction among the authorities and the Polish society within the country's borders and abroad. In this essay the Letter of 34' genesis, the process of collecting signatures and publication of the memorial were briefly described. The consequences of signing were also enumerated. The main focus was on the writers' attitudes toward the Letter of 34 .

The writers were divided between three groups - the signers of the document, the Communist Party supporters and those who agreed with the protest, but did not sign the letter. Their attitudes were exemplified by specific events related to the letter, e.g. meetings between the writers and the authorities, the making of the counter-letter and the general assembly of the Warsaw Branch of the Union of Polish Writers. The ambiguous attitude of Jarosław Iwaszkiewicz - the chairman of the aformentioned organization - was also discussed. It is valid to say that the supporters of the letter had an overwhelming majority within the writer community, although some voices of condemnation were certainly heard. The Letter of 34 contributed to the division in the Union of Polish Writers and foreshadowed a bigger protest in 1968.

Keywords: Letter od 34, writers, literature, culture, PRL, censorship, cultural policy, opposition, opportunism, Gomułka, Iwaszkiewicz, Słonimski. 